\title{
Konsumsi makanan tinggi natrium, kesukaan rasa asin, berat badan, dan tekanan darah pada anak sekolah
}

\author{
Natrium source food consumption, salty food preference, weight, and blood pressure among schoolchildren
}

\author{
Heni Hendriyani ${ }^{1}$, Enik Sulistyowati ${ }^{1}$, Astidio Noviardhi ${ }^{1}$
}

${ }^{1}$ Jurusan Gizi Politeknik Kesehatan Kementerian Kesehatan Semarang

\begin{abstract}
Background: It is a fact that natrium consumption relate with hypertension and the risk of heart disease and stroke. Eventhough it is common happened in later life, hypertension can be started in early age. Objective: The aim of the study is to identify salty food preference, high natrium food consumption, natrium intake, weight and its correlation with blood pressure among schoolchildren. Method: The study used crosssectional design. There were 151 samples from junior high school chosen by purposive sampling (there were 62 boys and 89 girls) aged 11 to 14 years old. Salty food preference data was asesed by eating snack with three different salt concentration. High and low natrium source food and natrium intake data were taken using semi quantitative food frequency questionnaire (SQ-FFQ). Blood pressure was measured by sphymomanometer digital. Bivariate analysis was used Chi-Square and Rank Spearman test. Results: The study revealed that $74,2 \%$ children prefer snack with salt level above recommendation $(>0,5$ $g$ salt per portion). There were $22,5 \%$ children have natrium intake from food only $\geq 2000 \mathrm{mg}$ (above recommendation). As much as $35,8 \%$ children fall into hypertension category based on their blood pressure (BP) level. There was a significant relationship between high natrium food consumption score with natrium intake $(p=0,002)$. There were significant correlation between weight with sistolic and diastolic $B P((p=0,000 ; r=-0,549$ and $p=0,000 ; r=-0,412)$. There were no correlation between natrium intake with sistolic and diastolic $B P(p=0,764 ; r=0,0025$ and $p=0,819 ; r=0,19)$. Conclusion: Healthy food and maintaining normal weight information and education must be done for children as early as possible.
\end{abstract}

KEY WORDS: blood pressure; natrium intake; salty food preference; schoolchildren; weight

\begin{abstract}
ABSTRAK
Latar belakang: Meningkatnya konsumsi natrium berhubungan dengan hipertensi dan meningkatnya risiko penyakit jantung dan stroke. Meskipun hipertensi, penyakit jantung, dan stroke biasanya terjadi pada orang dewasa, penyakit ini bisa berawal dari anak-anak. Tujuan: Menganalisis kesukaan rasa asin makanan, konsumsi makanan tinggi natrium, asupan natrium, berat badan, dan hubungannya dengan tekanan darah anak sekolah. Metode: Desain penelitian cross sectional dengan sampel penelitian anak SMP yang terpilih sejumlah 151 siswa (laki-laki 62 anak dan perempuan 89 anak) berusia antara 11 sampai 14 tahun. Data kesukaan rasa asin makanan diperoleh dengan mencicipi sosis solo dengan konsentrasi garam berbeda. Konsumsi makanan tinggi natrium, rendah natrium, dan asupan natrium diperoleh dengan mengisi semi kuantitatif Food Frequency Questionnaire. Tekanan darah diperoleh dengan alat ukur tekanan darah digital. Analisis data menggunakan uji Chi-Square dan Rank Spearman test. Hasil: Penelitian menunjukkan 74,2\% responden menyukai kudapan dengan konsentrasi garam di atas anjuran WHO (50 g snack dengan konsentrasi garam $>0,5 \mathrm{~g}$ ). Sejumlah $22,5 \%$ responden asupan natriumnya dari makanan saja mencapai $\geq 2000 \mathrm{mg}$. Responden dengan kategori hipertensi sebanyak 35,8\%. Terdapat hubungan bermakna antara konsumsi makanan tinggi natrium dan asupan natrium $(\mathrm{p}=0,002)$. Ada korelasi bermakna antara berat badan dengan tekanan sistolik dan diastolik $(\mathrm{p}=0,000 ; \mathrm{r}=-0,549$ dan $\mathrm{p}=0,000$; $\mathrm{r}=-0,412)$. Ditemukan korelasi yang tidak bermakna antara asupan natrium dengan tekanan darah sistolik dan diastolik $(\mathrm{p}=0,764$; $\mathrm{r}=0,0025$ dan $\mathrm{p}=0,819 ; \mathrm{r}=0,19$ ). Simpulan: Berat badan anak berhubungan dengan tekanan darah sistolik dan diastolik. Tidak ada korelasi antara asupan natrium dengan tekanan darah sistolik maupun diastolik. Informasi dan edukasi mengenai pilihan makanan yang sehat dan cara mempertahankan berat badan normal perlu diberikan kepada anak-anak sedini mungkin.
\end{abstract}

KATA KUNCI: tekanan darah; asupan natrium; kesukaan rasa asin makanan; anak sekolah; berat badan

Korespondensi: Heni Hendriyani, Jurusan Gizi Politeknik Kesehatan Kementerian Kesehatan Semarang, Jl. Wolter Monginsidi No.115, Pedurungan, Semarang, Telp (024)-6710378,Fax (024) 6708597,e-mail: heni_sahid@yahoo.com 


\section{PENDAHULUAN}

Penyakit tidak menular yang termasuk di dalamnya penyakit jantung dan stroke merupakan penyakit penyebab kematian dini utama di abad ke-21. Masyarakat di seluruh dunia mengonsumsi garam sebagai sumber utama natrium. Meningkatnya konsumsi natrium berhubungan dengan hipertensi dan meningkatnya risiko penyakit jantung dan stroke (1). Mengonsumsi terlalu banyak garam dapat berkontribusi pada kejadian hipertensi dan memicu penyakit jantung koroner dan stroke. Badan kesehatan dunia (WHO) mendorong pemerintah untuk mengimplementasikan aksi global untuk menurunkan penyakit ini (2).

Berdasarkan data Riskesdas 2013, saat ini Indonesia menghadapi tantangan utama dalam pengendalian penyakit yaitu adanya transisi epidemiologi. Hal ini menyebabkan munculnya beban ganda di Indonesia terkait pengendalian penyakit menular yang belum selesai sedangkan di sisi lain kasus penyakit tidak menular meningkat. Dalam kurun waktu 6 tahun (20072013), gambaran kejadian penyakit tidak menular adalah prevalensi penyakit jantung koroner $(1,5 \%)$ dan prevalensi stroke meningkat menjadi 12,1\% (3).

Perubahan gaya hidup dapat bermanifestasi pada perubahan pola aktivitas. Aktivitas fisik yang kurang merupakan salah satu faktor risiko terjadinya kegemukan dan obesitas. Banyak penelitian yang melaporkan bahwa kelebihan berat badan dan obesitas berhubungan dengan meningkatnya tekanan darah, penyakit, dan kematian akibat kardiovaskular saat dewasa (4). Meskipun hipertensi, penyakit jantung, dan stroke biasanya terjadi pada orang dewasa, penyakit ini bisa berawal dari anak-anak. Beberapa studi epidemiologi melaporkan bahwa saat ini prevalensi tekanan darah tinggi telah meningkat secara bermakna pada anak-anak dan remaja (5). Tingginya tekanan darah saat anak-anak biasanya akan menyebabkan hipertensi saat dewasa (6). Hipertensi saat dewasa merupakan penyebab utama kematian dini di seluruh dunia (7). Diperkirakan satu dari enam anak di Amerika usia 8-17 tahun sudah mengalami pre hipertensi atau hipertensi (8). Lebih jauh lagi, penelitian menemukan lebih dari 90\% anak sekolah di Amerika mengonsumsi natrium melebihi jumlah yang direkomendasikan (9). Data konsumsi natrium pada anak dan remaja di Indonesia belum banyak diambil, tetapi mengingat ketersediaan makanan yang tinggi kadar natrium seperti makanan olahan dan makanan cepat saji meningkat, maka hal ini dapat meningkatkan asupan natrium pada anak dan remaja di Indonesia. Tindakan pencegahan dini sangat diperlukan mengingat anak-anak dengan hipertensi akan lebih berisiko mengalami hipertensi saat dewasa (10).

Meningkatnya produksi makanan jadi dan berkembangnya restoran cepat saji menyebabkan terjadinya transformasi pola makan. Saat ini ketersediaan makanan semakin meningkat seiring dengan pesatnya perkembangan supermarket yang menjual makanan olahan. Pembelian makanan jadi oleh masyarakat yang umumnya mengandung pengawet seperti garam dan gula sudah tinggi sehingga konsumsi makanan yang tinggi natrium juga tinggi. Saat ini asupan garam telah lebih dominan berasal dari jumlah garam yang ditambahkan oleh para produsen makanan saat mengolahnya dibandingkan makanan yang diolah di rumah (5). Di lain pihak, apabila makanan yang disajikan keluarga tinggi natrium ataupun tidak sehat seimbang, maka anakanak juga akan cenderung mengikuti pola makan keluarga apalagi jika orangtua memiliki riwayat hipertensi. Pola makan yang tidak sehat berkaitan dengan hipertensi (11).

Data mengenai konsumsi makanan yang tinggi natrium pada anak-anak di Indonesia belum banyak diambil. Selain itu, masalah konsumsi garam pada masyarakat sudah harus diperhatikan terutama pada anak-anak karena pola makan dan kesukaan terhadap rasa makanan dimulai dari anak-anak. Upaya untuk mengetahui karakteristik dan asupan garam anak-anak di Indonesia perlu dilakukan sebagai dasar untuk pencegahan sedini mungkin. Selain itu, pengukuran tekanan darah perlu dilakukan pada anak-anak sebagai deteksi awal terjadinya hipertensi. Dengan demikian, penelitian ini penting untuk dilakukan dengan tujuan menganalisis kesukaan rasa asin, konsumsi makanan tinggi natrium, asupan natrium, berat badan, dan hubungannya dengan tekanan darah pada anak sekolah.

\section{BAHAN DAN METODE}

Desain penelitian ini adalah cross sectional yang dilakukan di Sekolah Menengah Pertama (SMP) Negeri 9 di Kota Semarang pada bulan April - Mei 2015. Populasi penelitian adalah anak SMP Negeri 9 kelas 7 dan kelas 
8 di wilayah Kota Semarang dengan jumlah populasi 630 anak. Sampel penelitian adalah anak yang terpilih sebagai sampel dengan purposive sampling dengan kriteria inklusi sehat dan bersedia menjadi sampel penelitian sedangkan kriteria eksklusi adalah responden yang sedang berpuasa dan sedang sakit. Jumlah sampel penelitian ini sebesar 151 anak (laki-laki 62 anak dan perempuan 89 anak) dengan usia berkisar 11 sampai 14 tahun, diperoleh menggunakan rumus besar sampel untuk desain survei dengan signifikan level sebesar 1,96; asumsi prevalensi pola makan tinggi natrium sebesar $50 \%(0,5)$; dan derajat akurasi sebesar 0,08 (8).

Karakteristik demografi dikumpulkan dengan wawancara menggunakan kuesioner. Pola konsumsi makanan tinggi natrium dan rendah natrium dikumpulkan dengan wawancara menggunakan semi quantitative food frequency questionnaire (SQ-FFQ) dan dilakukan oleh enumerator lulusan Diploma III Gizi. Kesukaan rasa asin pada makanan kudapan lokal dikumpulkan dengan mencatat makanan kudapan lokal yang paling disukai rasanya menggunakan kuesioner. Ada tiga pilihan makanan kudapan dengan penambahan konsentrasi garam yang berbeda (Resep 1, 2, dan 3). Perhitungan jumlah garam yang ditambahkan dengan asumsi penggunaan garam per hari $5 \mathrm{~g} \mathrm{(12)} \mathrm{yaitu} \mathrm{pagi:} 30 \%$, snack siang: $5 \%$, siang: $30 \%$, snack sore: $5 \%$, dan malam: $30 \%$.

Berat badan ditimbang menggunakan timbangan digital dengan ketelitian $0,1 \mathrm{~kg}$, ketika ditimbang para siswa melepas sepatu dan meminimalkan atribut lain yang dapat menambah berat. Tinggi badan diukur menggunakan microtoice dengan ketelitian $0,1 \mathrm{~cm}$. Pada saat diukur tinggi badan, para siswa berdiri tegak, ujung belakang kaki, pantat, bahu, dan kepala menempel pada dinding. Pengumpulan data, penimbangan berat badan, dan pengukuran tinggi badan dilakukan oleh lulusan program diploma III Gizi. Sementara tekanan darah diukur dengan sphygmomanometer digital dan yang mengukur adalah perawat dengan pendidikan S1 keperawatan sebanyak 3 kali pengukuran pada hari yang sama. Kategori tekanan darah diperoleh dengan cara mengetahui persentil tinggi badan pada tabel tekanan darah berdasarkan umur, jenis kelamin, dan persentil tinggi badan anak dari the fourth report on the diagnosis, evaluation, and treatment of high blood pressure in children and adolescents anak usia 1 17 tahun. Jika tekanan darah sistolik dan atau diastoliknya terletak pada lebih dari 95 persentil maka anak tersebut termasuk dalam kategori hipertensi (13).

Kategori pendidikan adalah pendidikan dasar jika menamatkan SD/MI, pendidikan menengahjika menamatkan SLTP/ SLTA, dan pendidikan tinggi jika tamat perguruan tinggi. Evaluasi daya terima dilakukan pada pilihan sosis solo yang paling disukai. Siswa diberikan kuesioner daya terima dengan nilai rentang dari 1 sampai 4. Nilai 1 paling tidak suka dan nilai 4 paling suka. Frekuensi makan dibagi dalam kategori sering dan jarang yaitu sering jika responden mengonsumsi makanan dimaksud $>1$ kali sehari, $1 \mathrm{x}$ sehari, 3-6x seminggu, dan 1-2x seminggu sedangkan dikatakan jarang jika mengonsumsi 2 minggu sekali, 1 x sebulan, dan

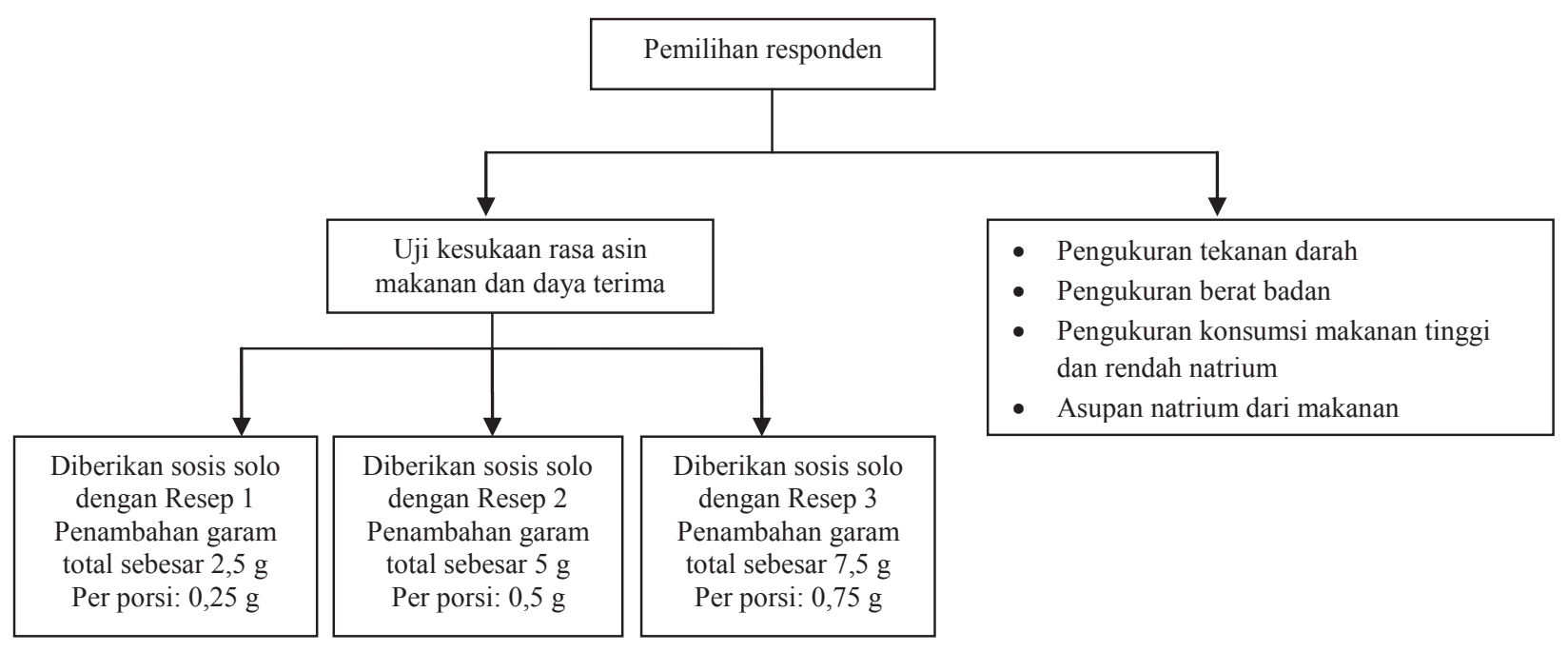

Gambar 1. Diagram pelaksanaan penelitian 
tidak pernah. Makanan kudapan lokal yang dipilih adalah sosis solo dengan pertimbangan merupakan kudapan lokal khas Jawa Tengah yang digemari oleh anak-anak maupun dewasa, rasanya enak, dan umum diperoleh di warung atau kantin sekolah. Pembuatan makanan kudapan lokal dilakukan di Laboratorium Kuliner Jurusan Gizi Poltekkes Kemenkes Semarang oleh tim peneliti dibantu oleh tenaga pemasak. Modifikasi resep dan uji coba pemasakan telah dilakukan sebelum pelaksanaan pemasakan sosis solo untuk penelitian. Pemasakan dilakukan satu hari sebelum pengambilan data. Alur penelitian secara lengkap dijelaskan dalam Gambar 1.

Analisis univariat dilakukan untuk mendapatkan gambaran umum responden dan karakteristik demografi serta menggunakan program Nutrisurvey 2007 untuk menganalisis asupan natrium. Analisis bivariat dilakukan dengan uji Chi-Square, Mann-Whitney, dan korelasi Rank Spearman. Ethical clearance diperoleh dari Komisi Etik Fakultas Kesehatan Masyarakat Universitas Diponegoro Semarang. Informed consent diberikan kepada para siswa dan mereka yang menandatangani adalah yang memutuskan untuk bersedia menjadi sampel dan terlebih dahulu diberi penjelasan.

\section{HASIL}

\section{Karakteristik responden}

Tabel 1 menunjukkan bahwa sebanyak 33,1\% responden memiliki riwayat keluarga hipertensi serta memiliki ibu dan ayah dengan pendidikan tinggi (tamat perguruan tinggi) masing-masing 48,4\% dan 54,3\%. Sebagian besar ibu tidak bekerja (42,4\%) sedangkan ayah sebagian besar bekerja sebagai wiraswasta/layan jasa/ dagang. Lebih lanjut, sebagian besar responden berumur 13-14 tahun (66,9\%) dan berjenis kelamin perempuan $(58,9 \%)$. Sebagian besar anak sekolah $(44,4)$ menyukai kudapan lokal dengan konsentrasi garam yang lebih dari anjuran WHO (0,5 g per porsi). Bahkan, sebesar 29,8\% dari responden menyukai kudapan yang memiliki konsentrasi garam 3 kali lipat anjuran WHO (0,75 g per porsi). Hampir sebagian besar sampel memiliki daya terima makanan kudapan lokal yang baik yaitu tekstur sesuai $(88,8 \%)$, warna menarik $(82,1 \%)$, aroma yang sedap $(82,8 \%)$, bumbu yang sedap $(86,8 \%)$ serta matang
Tabel 1. Distribusi karakteristik responden

\begin{tabular}{|c|c|c|}
\hline Variabel & $\mathbf{n}$ & $\%$ \\
\hline \multicolumn{3}{|l|}{ Umur (tahun) } \\
\hline $11-12$ & 50 & 33,2 \\
\hline $13-14$ & 101 & 66,9 \\
\hline \multicolumn{3}{|l|}{ Jenis kelamin } \\
\hline Laki-laki & 62 & 41,1 \\
\hline Perempuan & 89 & 58,9 \\
\hline \multicolumn{3}{|l|}{ Riwayat Hipertensi Keluarga } \\
\hline Ibu & 21 & 13,9 \\
\hline Ayah & 24 & 15,9 \\
\hline Nenek/Kakek & 5 & 3,3 \\
\hline Tidak ada & 101 & 66,9 \\
\hline \multicolumn{3}{|l|}{ Pendidikan Ibu } \\
\hline Tamat SD/MI & 9 & 6,0 \\
\hline Tamat SLTP/MTS & 11 & 7,3 \\
\hline Tamat SLTA/MA & 58 & 38,4 \\
\hline Tamat PT & 73 & 48,4 \\
\hline \multicolumn{3}{|l|}{ Pendidikan Ayah } \\
\hline Tamat SD/MI & 3 & 2,0 \\
\hline Tamat SLTP/MTS & 7 & 4,6 \\
\hline Tamat SLTA/MA & 59 & 39,1 \\
\hline Tamat PT & 82 & 54,3 \\
\hline \multicolumn{3}{|l|}{ Pekerjaan Ibu } \\
\hline Tidak kerja & 64 & 42,4 \\
\hline PNS/Pegawai/TNI POLRI & 30 & 19,9 \\
\hline Wiraswasta/Layan jasa/Dagang & 36 & 23,8 \\
\hline Buruh/lainnya & 21 & 13,9 \\
\hline \multicolumn{3}{|l|}{ Pekerjaan Ayah } \\
\hline Tidak kerja & 3 & 2,0 \\
\hline PNS/Pegawai & 48 & 31,8 \\
\hline Wiraswasta/Layan jasa/Dagang & 62 & 41,1 \\
\hline Petani/Nelayan & 2 & 1,3 \\
\hline Buruh/lainnya & 36 & 24,9 \\
\hline \multicolumn{3}{|l|}{ Kesukaan rasa asin } \\
\hline Kode 164 (0,25 g/porsi) & 39 & 25,8 \\
\hline Kode $287(0,5$ g/porsi $)$ & 67 & 44,4 \\
\hline Kode 539 (0,75 g/porsi) & 45 & 29,8 \\
\hline \multicolumn{3}{|l|}{ Asupan natrium (mg) } \\
\hline$<2000$ & 117 & 77,5 \\
\hline$\geq 2000$ & 34 & 22,5 \\
\hline \multicolumn{3}{|l|}{ Status tekanan darah } \\
\hline Hipertensi & 54 & 35,8 \\
\hline Tidak Hipertensi & 97 & 64,2 \\
\hline
\end{tabular}

$(94,1 \%)$. Hal ini dapat diasumsikan bahwa anak-anak suka dengan makanan kudapan lokal jika dimasak dengan baik. Mereka akan mau mengonsumsi jajanan lokal jika tersedia di rumah dan dapat menggantikan jajanan olahan yang biasanya tinggi natrium. 
Sebanyak $22,5 \%$ responden asupan natriumnya melebihi anjuran, padahal asupan natrium ini baru berasal dari makanan saja belum ditambah dari garam yang digunakan pada masakan. Sejumlah 35,8\% anak status tekanan darahnya lebih atau hipertensi menurut The fourth report on the diagnosis, evaluation, and treatment of high blood pressure in children and adolescents anak usia 1 - 17 tahun (13).
Hasil analisis menunjukkan rerata asupan natrium 1503,84 mg dengan nilai maksimum 4915,2 mg. Data asupan natrium diperoleh dari SQ-FFQ hanya dari makanan saja belum termasuk garam yang berasal dari masakan atau yang ditambahkan pada masakan. Rerata tekanan darah sistolik 116,45 $\mathrm{mmHg}$ dan rerata tekanan darah diastolik 69,62 mmHg. Sementara rerata untuk berat badan sebesar $48,28 \mathrm{~kg}$ dengan berat minimal 28 $\mathrm{kg}$ dan maksimal 105,8 kg.

Tabel 2. Distribusi pola konsumsi makanan tinggi natrium

\begin{tabular}{|c|c|c|c|c|c|c|c|}
\hline \multirow{2}{*}{ Jenis makanan } & $>1 x$ sehari & 1x sehari & 3-6x seminggu & 1-2x seminggu & 2 mg sekali & 1x sebulan & Tidak pernah \\
\hline & n (\%) & n (\%) & n (\%) & n (\%) & n (\%) & n (\%) & n (\%) \\
\hline Cracker & $10(6,6)$ & $12(7,9)$ & $11(7,3)$ & $44(29,1)$ & $19(12,6)$ & $33(21,9)$ & $22(14,6)$ \\
\hline Roti coklat & $4(2,6)$ & $15(9,9)$ & $26(17,2)$ & $42(27,8)$ & $31(20,5)$ & $23(15,2)$ & $10(6,6)$ \\
\hline Roti susu & $5(3,3)$ & $18(11,9)$ & $19(12,6)$ & $23(15,2)$ & $25(16,6)$ & $31(20,5)$ & $30(19,9)$ \\
\hline Corned beef & $0(0,0)$ & $1(0,7)$ & $9(6,0)$ & $12(7,9)$ & $14(9,3)$ & $57(37,7)$ & $58(38,4)$ \\
\hline Keju & $5(3,3)$ & $4(2,6)$ & $23(15,2)$ & $36(23,8)$ & $22(14,6)$ & $52(34,4)$ & $9(6,0)$ \\
\hline Sosis & $11(7,3)$ & $9(6,0)$ & $34(22,5)$ & $49(32,5)$ & $34(22,5)$ & $11(7,3)$ & $3(2,0)$ \\
\hline Daging ayam & $11(7,3)$ & $14(9,3)$ & $60(39,7)$ & $42(27,8)$ & $13(18,6)$ & $8(5,3)$ & $3(2,0)$ \\
\hline Daging sapi & $5(3,3)$ & $3(2,0)$ & $11(7,3)$ & $30(19,9)$ & $21(13,9)$ & $53(35,1)$ & $28(18,5)$ \\
\hline Daging bebek & $0(0,0)$ & $1(0,7)$ & $8(5,3)$ & $10(6,6)$ & $19(12,6)$ & $67(44,4)$ & $46(30,5)$ \\
\hline Sarden & $1(0,7)$ & $0(0,0)$ & $6(4,0)$ & $13(8,6)$ & $16(10,6)$ & $71(47,0)$ & $44(29,1)$ \\
\hline Telur ayam & $22(14,6)$ & $29(19,2)$ & $59(39,1)$ & $31(20,5)$ & $6(4,0)$ & $1(0,7)$ & $3(2,0)$ \\
\hline Udang & $1(0,7)$ & $6(4,0)$ & $14(9,3)$ & $37(24,5)$ & $33(21,9)$ & $40(26,5)$ & $20(13,2)$ \\
\hline Ikan & $2(1,3)$ & $10(6,6)$ & $40(26,5)$ & $39(25,8)$ & $30(19,9)$ & $24(15,9)$ & $6(4,0$ \\
\hline Babat & $1(0,7)$ & $4(2,6)$ & $11(7,3)$ & $7(4,6)$ & $17(11,3)$ & $39(25,8)$ & $72(47,7)$ \\
\hline Usus & $0(0,0)$ & $2(1,3)$ & $10(6,6)$ & $18(11,9)$ & $18(11,9)$ & $42(27,8)$ & $61(40,4)$ \\
\hline Ikan asin & $1(0,7)$ & $5(3,3)$ & $7(4,6)$ & $23(15,2)$ & $16(10,6)$ & $55(36,4)$ & $44(29,1)$ \\
\hline Kecap & $23(15,2)$ & $41(27,2)$ & $37(24,5)$ & $28(18,5)$ & $11(7,3)$ & $6(4,0)$ & $5(3,3)$ \\
\hline Susu full cream & $13(8,6)$ & $19(12,6)$ & $29(19,2)$ & $16(10,6)$ & $16(10,6)$ & $26(17,2)$ & $32(21,2)$ \\
\hline Coklat susu & $14(9,3)$ & $30(19,9)$ & $19(12,6)$ & $25(16,6)$ & $16(10,6)$ & $26(17,2)$ & $21(13,9)$ \\
\hline Es krim & $4(2,6)$ & $7(4,6)$ & $29(19,2)$ & $41(27,2)$ & $33(21,9)$ & $34(22,5)$ & $3(2,0)$ \\
\hline Margarin & $6(4,0)$ & $18(11,9)$ & $15(9,9)$ & $15(9,9)$ & $21(13,9)$ & $38(25,2)$ & $38(25,2)$ \\
\hline Mentega & $5(3,3)$ & $18(11,9)$ & $13(8,6)$ & $16(10,6)$ & $20(13,2)$ & $39(25,8)$ & $40(26,5)$ \\
\hline Kaldu blok & $2(1,3)$ & $6(4,0)$ & $9(6,0)$ & $10(6,6)$ & $9(6,0)$ & $26(17,2)$ & $89(58,9)$ \\
\hline Selai & $1(0,7)$ & $8(5,3)$ & $12(7,9)$ & $19(12,6)$ & $19(12,6)$ & $52(34,4)$ & $40(26,5)$ \\
\hline Saos tomat & $2(1,3)$ & $17(11,3)$ & $23(15,2)$ & $18(11,9)$ & $21(13,9)$ & $33(21,9)$ & $37(24,5)$ \\
\hline Bihun goreng & $1(0,7)$ & $6(4,0)$ & $10(6,6)$ & $23(15,2)$ & $24(15,9)$ & $43(28,5)$ & $44(29,1)$ \\
\hline Mie goreng & $2(1,3)$ & $13(8,6)$ & $25(16,6)$ & $58(38,4)$ & $26(17,2)$ & $24(15,9)$ & $3(2,0)$ \\
\hline Bakso & $3(2,0)$ & $6(4,0)$ & $10(6,6)$ & $39(25,8)$ & $40(26,5)$ & $47(31,1)$ & $6(4,0)$ \\
\hline Bubur ayam & $3(2,0)$ & $3(2,0)$ & $11(7,3)$ & $28(18,5)$ & $24(15,9)$ & $59(39,1)$ & $23(15,2)$ \\
\hline Martabak & $3(2,0)$ & $5(3,3)$ & $9(6,0)$ & $30(19,9)$ & $35(23,2)$ & $56(37,1)$ & $13(8,6)$ \\
\hline Mie ayam & $0(0,0)$ & $5(3,3)$ & $10(6,6)$ & $29(19,2)$ & $42(27,8)$ & $51(33,8)$ & $14(9,3)$ \\
\hline Nasi uduk & $0(0,0)$ & $2(1,3)$ & $10(6,6)$ & $14(9,3)$ & $21(13,9)$ & $52(34,4)$ & $52(34,4)$ \\
\hline Kerupuk kemplang & $2(1,3)$ & $2(1,3)$ & $4(2,6)$ & $10(6,6)$ & $11(7,3)$ & $27(17,9)$ & $95(62,9)$ \\
\hline Keripik kentang & $2(1,3)$ & $5(3,3)$ & $11(7,3)$ & $23(15,2)$ & $29(19,2)$ & $48(31,8)$ & $33(21,9)$ \\
\hline Kerupuk udang & $1(0,7)$ & $4(2,6)$ & $13(8,6)$ & $17(11,3)$ & $28(18,5)$ & $52(34,4)$ & $36(23,8)$ \\
\hline Beef burger & $3(2,0)$ & $1(0,7)$ & $9(6,0)$ & $13(8,6)$ & $22(14,6)$ & $75(49,7)$ & $28(18,5)$ \\
\hline Telur asin & $2(1,3)$ & $2(1,3)$ & $9(6,0)$ & $18(11,9)$ & $21(13,9)$ & $68(45,0)$ & $31(20,5)$ \\
\hline
\end{tabular}


Tabel 3. Distribusi pola konsumsi makanan rendah natrium

\begin{tabular}{|c|c|c|c|c|c|c|c|}
\hline \multirow[t]{2}{*}{ Jenis makanan } & $>1 x$ sehari & $\begin{array}{c}1 \mathrm{x} \\
\text { sehari }\end{array}$ & $\begin{array}{c}\text { 3-6x sem- } \\
\text { inggu }\end{array}$ & $\begin{array}{c}\text { 1-2x sem- } \\
\text { inggu }\end{array}$ & 2 mg sekali & $1 \mathrm{x}$ sebulan & $\begin{array}{c}\text { Tidak } \\
\text { pernah }\end{array}$ \\
\hline & n (\%) & n (\%) & n (\%) & n (\%) & n (\%) & n (\%) & n (\%) \\
\hline Bayam & & $17(11,3)$ & \multirow{4}{*}{$\begin{array}{c}31(20,5) \\
13(8,6) \\
25(16,6) \\
21(13,9)\end{array}$} & $55(36,4)$ & \multirow{4}{*}{$\begin{array}{l}22(14,6) \\
27(17,9) \\
24(15,9) \\
21(13,9)\end{array}$} & $11(7,3)$ & $4(2,6)$ \\
\hline Buncis & $3(2,0)$ & $7(4,6)$ & & $33(21,9)$ & & $26(17,2)$ & $42(27,8)$ \\
\hline Kangkung & \multirow{2}{*}{$\begin{array}{l}5(3,3) \\
9(6,0)\end{array}$} & $12(7,9)$ & & $51(33,8)$ & & $20(13,2)$ & $14(9,3)$ \\
\hline Ketimun & & $11(7,3)$ & & $37(24,5)$ & & $21(13,9)$ & $31(20,5)$ \\
\hline Kol & \multirow{2}{*}{$\begin{array}{l}6(4,0) \\
8(5,3)\end{array}$} & $13(8,6)$ & $22(14,6)$ & $43(28,5)$ & \multirow{2}{*}{$\begin{array}{l}22(14,6) \\
16(10,6)\end{array}$} & $20(13,2)$ & $25(16,6)$ \\
\hline Tomat & & $15(9,9)$ & $23(15,2)$ & $35(23,2)$ & & $25(16,6)$ & $29(19,2)$ \\
\hline Wortel & \multirow{2}{*}{$\begin{array}{c}10(6,6) \\
4(2,6)\end{array}$} & $23(15,2)$ & $41(27,2)$ & $40(26,5)$ & \multirow{2}{*}{$\begin{array}{l}15(9,9) \\
19(126)\end{array}$} & $17(11,3)$ & $5(3,3)$ \\
\hline Alpukat & & $5(3,3)$ & $14(9,3)$ & $20(13,2)$ & & $65(43,0)$ & $24(15,9)$ \\
\hline Anggur & \multirow{2}{*}{$\begin{array}{l}0(0,0) \\
2(1,3)\end{array}$} & $5(3,3)$ & $8(5,3)$ & & $21(13,9)$ & $69(45,7)$ & $32(21,2)$ \\
\hline Apel & & $10(6,6)$ & $13(8,6)$ & $25(16,6)$ & \multirow{2}{*}{$\begin{array}{l}25(16,6) \\
17(11,3)\end{array}$} & $61(40,4)$ & $15(9,9)$ \\
\hline Belimbing & \multirow{2}{*}{$\begin{array}{l}3(2,0) \\
6(4,0)\end{array}$} & & $6(4,0)$ & & & $60(39,7)$ & $45(29,8)$ \\
\hline Jeruk manis & & $17(11,3)$ & $24(15,9)$ & $37(24,5)$ & \multirow{3}{*}{$\begin{array}{l}19(12,6) \\
16(10,6) \\
19(12,6)\end{array}$} & $39(25,8)$ & $9(6,0)$ \\
\hline Nanas & \multirow{2}{*}{$\begin{array}{l}2(1,3) \\
4(2,6)\end{array}$} & $3(2,0)$ & $10(6,6)$ & $11(7,3)$ & & $64(42,4)$ & $45(29,8)$ \\
\hline Pepaya & & $14(9,3)$ & $17(11,3)$ & $32(21,2)$ & & $42(27,8)$ & $23(15,2)$ \\
\hline Pisang & \multirow{2}{*}{$\begin{array}{l}8(5,3) \\
6(4,0)\end{array}$} & $17(11,3)$ & $27(17,9)$ & $40(26,5)$ & $\begin{array}{l}18(11,9) \\
22(14,6)\end{array}$ & $31(20,5)$ & $10(6,6)$ \\
\hline Semangka & & $7(4,6)$ & $19(12,6)$ & $30(19,9)$ & $22(14,6)$ & $51(33,8)$ & $16(10,6)$ \\
\hline Jambu biji & \multirow{2}{*}{$\begin{array}{l}6(4,0) \\
4(2,6)\end{array}$} & $4(2,6)$ & $9(6,0)$ & $26(17,2)$ & \multirow{2}{*}{$\begin{array}{l}26(17,2) \\
18(11,9)\end{array}$} & $49(32,5)$ & $31(20,5)$ \\
\hline Melon & & $9(6,0)$ & $18(11,9)$ & $23(15,2)$ & & $62(41,1)$ & $17(11,3)$ \\
\hline
\end{tabular}

Tabel 4. Hubungan antara konsumsi makanan tinggi natrium dan rendah natrium dengan asupan natrium

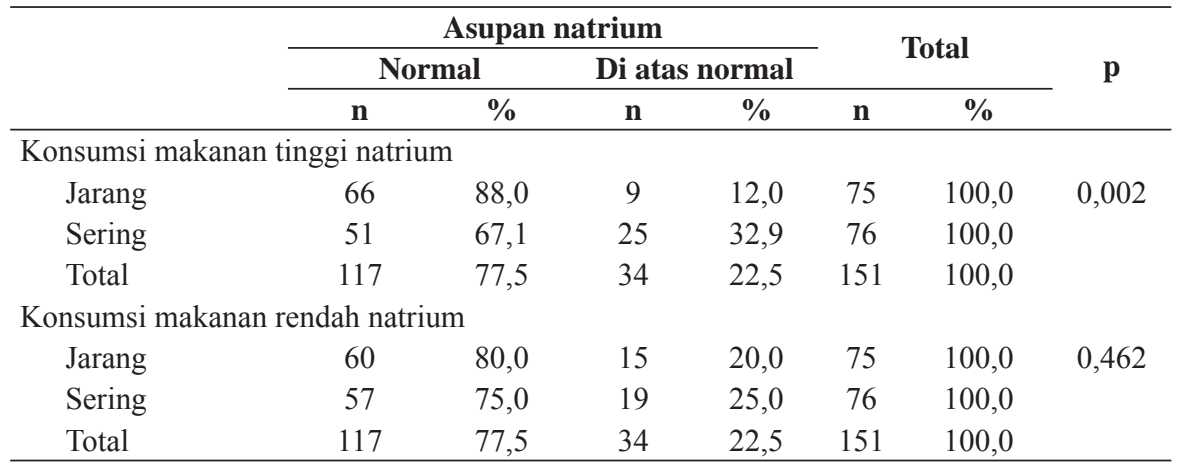

Pola makan makanan tinggi natrium dan rendah natrium

Dari Tabel 2 terlihat beberapa makanan tinggi natrium yang paling sering dikonsumsi $(>1 \mathrm{x}$ sehari, 1x sehari, 3-6x seminggu dan 1-2x seminggu) oleh responden diantaranya kecap, coklat susu, daging ayam, telur ayam, cracker, roti coklat, sosis, es krim, dan mie goreng.

Tabel 3 menunjukkan pola konsumsi makanan rendah natrium sebagian besar responden termasuk kategori jarang. Hal ini menunjukkan bahwa konsumsi sayur dan buah anak-anak masih kurang. Hasil analisis dengan Chi-Square menunjukkan hubungan bermakna antara konsumsi makanan tinggi natrium dan rendah natrium dengan asupan natrium (Tabel 4). Hasil analisis menunjukkan terdapat hubungan yang bermakna antara konsumsi makanan tinggi natrium dengan asupan natrium $(\mathrm{p}=0,002)$. Proporsi anak yang asupan natriumnya di atas normal lebih besar pada anak yang sering mengonsumsi makanan tinggi natrium yaitu sebanyak $32,9 \%$. Sebaliknya, tidak ditemukan hubungan yang bermakna antara konsumsi makanan rendah natrium 
dengan asupan natrium. Proporsi anak yang sering dan jarang mengonsumsi sayur dan buah hampir sama yaitu $76 \%$ dan $75 \%$.

\section{Korelasi antara asupan natrium, skor pola konsumsi makanan tinggi natrium, dan skor pola konsumsi makanan rendah natrium dengan tekanan sistolik dan diastolik}

Tabel 5 menunjukkan bahwa tidak ditemukan hubungan yang bermakna pada variabel asupan natrium, konsumsi makanan tinggi natrium dan rendah natrium dengan tekanan darah sistolik dan diastolik. Kebiasaan makan dan asupan natrium belum bermanifestasi klinik terhadap tekanan darah, mengingat usia responden yang masih anak-anak. Sementara itu, berat badan memiliki korelasi positif yang cukup kuat dengan tekanan darah sistolik dan diastolik seperti yang terlihat pada Gambar 2 dan Gambar 3.

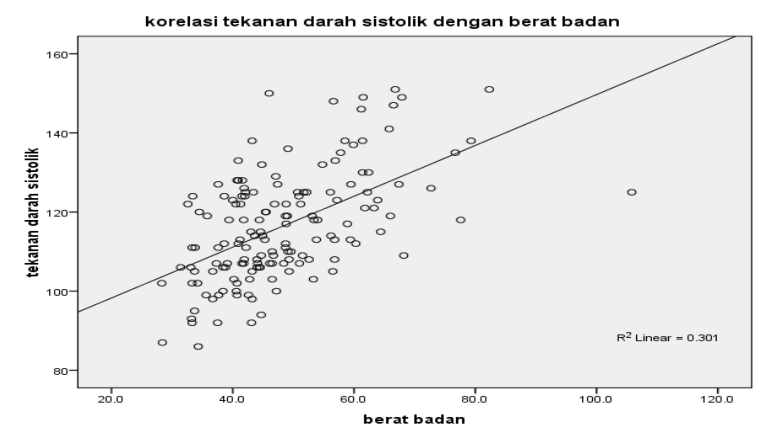

Gambar 2. Korelasi berat badan dengan tekanan darah sistolik

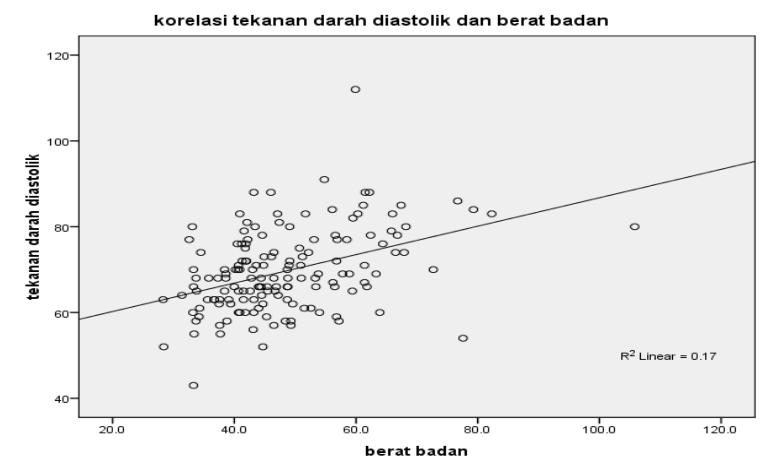

Gambar 3. Korelasi berat badan dengan tekanan darah diastolik
Tabel 5. Korelasi antara asupan natrium, skor konsumsi makanan tinggi natrium, skor konsumsi makanan rendah natrium, dan berat badan dengan tekanan sistolik dan diastolik

\begin{tabular}{lcccc}
\hline \multicolumn{1}{c}{ Variabel } & \multicolumn{4}{c}{ Tekanan darah } \\
\hline & \multicolumn{2}{c}{ Sistolik } & \multicolumn{2}{c}{ Diastolik } \\
\cline { 2 - 5 } & $\mathbf{r}$ & $\mathbf{p}$ & $\mathbf{r}$ & $\mathrm{p}$ \\
\hline $\begin{array}{l}\text { Asupan natrium } \\
\begin{array}{l}\text { Skor konsumsi makanan } \\
\text { tinggi natrium }\end{array}\end{array}$ & $-0,025$ & 0,764 & 0,19 & 0,819 \\
$\begin{array}{l}\text { Skor konsumsi makanan } \\
\text { rendah natrium }\end{array}$ & 0,415 & $-0,093$ & 0,254 \\
Berat badan & 0,031 & 0,704 & $-0,004$ & 0,960 \\
\hline
\end{tabular}

\section{BAHASAN}

Hasil penelitian menunjukkan adanya hubungan yang bermakna antara konsumsi makanan tinggi natrium dengan asupan natrium $(\mathrm{p}=0,002)$. Proporsi anak yang asupan natriumnya di atas normal lebih besar pada anak yang mengonsumsi makanan tinggi natriumnya sering $(32,9 \%)$. Semakin sering anak-anak mengonsumsi makanan tinggi natrium, maka asupan natriumnya juga akan semakin tinggi. Natrium secara alami terdapat dalam berbagai makanan seperti susu, daging, dan kerang. Natrium terkandung dalam jumlah banyak pada makanan yang diproses atau makanan jadi seperti roti, krakers, daging olahan, dan makanan kudapan/snack olahan $(14,15)$.

Makanan seperti kecap dan saus ikan juga mengandung natrium dalam jumlah banyak. Pola makan yang tinggi makanan olahan dan rendah buah dan sayur biasanya tinggi natrium $(14,15)$. Beberapa makanan tinggi natrium dikonsumsi sering ( $>1 \mathrm{x}$ sehari, 1x sehari, 3-6x seminggu dan 1-2x seminggu) oleh responden pada penelitian ini diantaranya kecap, coklat susu, daging ayam, telur ayam, cracker, roti coklat, sosis, es krim, dan mie goreng. Kebanyakan orangtua tidak menyadari hal itu. Selain itu, makan di restoran siap saji juga bisa menyumbang kosumsi garam yang tak terkendali pada anak-anak (16). Hasil studi ini sejalan dengan studi yang dilakukan di Finlandia yang menunjukkan bahwa asupan garam banyak berasal dari makanan olahan seperti roti, daging, dan produk ikan (17). Meningkatnya produksi makanan jadi, urbanisasi yang cepat, dan perubahan gaya hidup menyebabkan terjadinya transformasi pola makan. 
Keadaan tersebut didukung dengan ketersediaan yang meningkat dan harga yang terjangkau sehingga daya beli dan konsumsi masyarakat ikut meningkat.

Sebagian besar anak sekolah (44,4\%) menyukai kudapan lokal dengan konsentrasi garam yang lebih dari anjuran WHO (0,5 g per porsi). Bahkan, sebesar 29,8\% responden menyukai kudapan yang memiliki konsentrasi garam 3 kali lipat dari anjuran WHO (0,75 g per porsi). Penelitian yang dilakukan di Jepang menunjukkan sebesar 90\% anak-anak lebih menyukai makanan yang mengandung garam tinggi diantaranya snack kemasan dan mie instan (16).

Hasil analisis antara asupan natrium, skor konsumsi makanan tinggi natrium, dan skor konsumsi makanan rendah natrium dengan tekanan darah sistolik dan diastolik tidak menunjukkan hubungan yang bermakna. Hal ini dapat diasumsikan bahwa kebiasaan makan dan asupan natrium belum bermanifestasi klinik ke tekanan darah, mengingat usia responden yang masih anak-anak. Peran orangtua sangat penting dalam upaya mengatasi anak-anak agar tidak kelebihan konsumsi garam. Usaha yang dapat dilakukan diantaranya adalah membiasakan anak untuk mengonsumsi buah-buahan dan sayuran setiap hari dan mengurangi garam pada masakan di rumah. Anak-anak dengan hipertensi akan memperoleh manfaat dari mengonsumsi makanan berupa buah dan sayuran, serat, dan produk rendah lemak untuk menurunkan asupan natriumnya (4).

Proporsi anak yang masuk dalam kategori hipertensi pada penelitian ini cukup tinggi yaitu mencapai 35,8\% dan keadaan ini harus mulai menjadi perhatian. Studi-studi epidemiologi melaporkan bahwa saat ini prevalensi tekanan darah tinggi telah meningkat secara bermakna pada anak-anak dan remaja (5). Hasil penelitian di Lithuania juga menunjukkan proporsi yang cukup tinggi yaitu 25,1\% (5). Tingginya tekanan darah pada anak-anak biasanya akan menyebabkan hipertensi saat dewasa (6). Hipertensi saat dewasa merupakan penyebab utama kematian dini di seluruh dunia (7). Anak yang menderita hipertensi harus ditangani dengan cara kombinasi dari pengobatan dan modifikasi gaya hidup yaitu konsumsi makanan sehat seimbang dan rutin beraktivitas fisik (4). Tekanan darah pada saat anak-anak berhubungan bermakna dengan tekanan darah pada saat dewasa, artinya anak-anak yang memiliki tekanan darah yang meningkat akan berisiko memiliki hipertensi dan penyakit lain yang berhubungan dengan hipertensi di saat dewasa (18). Tekanan darah yang meningkat saat anakanak berkontribusi pada patologi penyakit kardiovaskuler selama masa anak-anak tersebut (19).

WHO telah melakukan review sistematis berbagai literatur mengenai asupan natrium dan tekanan darah pada anak-anak. Hasilnya menunjukkan bahwa penurunan asupan natrium pada anak-anak dapat menurunkan tekanan darah sistolik sebesar 0,84 mmHg (95\%CI: 0,251,43 ) dan tekanan darah diastolik sebesar $0,87 \mathrm{mmHg}$ (95\%CI: 0,14-1,60) (20). Perlu dilakukan pengendalian sedini mungkin lewat pola makan yang sehat untuk mengatasi peningkatan tekanan darah sistolik dan diastolik pada anak-anak.

Penelitian ini juga menemukan bahwa berat badan memiliki korelasi positif yang cukup kuat dengan tekanan darah sistolik dan diastolik ( $\mathrm{p}=0,000 ; \mathrm{r}=-0,535$ dan $\mathrm{p}=0,000 ; \mathrm{r}=-0,391$ ). Hal ini sejalan dengan penelitian sebelumnya yang menemukan bahwa asupan natrium berkorelasi positif dengan tekanan darah sistolik dan korelasinya akan lebih besar pada anak yang overweight dan obesitas (21). Penelitian yang dilakukan di Bahama menunjukkan anak sekolah yang kelebihan berat badan/ obesitas berisiko 2,7 kali untuk mengalami kenaikan tekanan darah (22). Tekanan darah sistolik dan diastolik memiliki korelasi bermakna dengan umur, tinggi badan, berat badan, dan indeks massa tubuh (IMT) (19). Demikian pula studi yang dilakukan oleh di Yogyakarta (23), di Lithuania (5), dan di India (24) yang melaporkan bahwa berat badan berhubungan dengan tekanan darah pada anak dan remaja. Penelitian menunjukkan bahwa pengaturan gaya hidup seperti penurunan berat badan, meningkatkan konsumsi tinggi serat dan rendah lemak, mengurangi asupan garam, dan meningkatkan aktivitas fisik dapat mencegah terjadinya hipertensi. Berat badan berkaitan erat dengan tekanan darah dan peningkatan berat badan yang berlebih diikuti oleh peningkatan tekanan darah. Dengan demikian, mempertahankan berat badan normal dapat mencegah terjadinya hipertensi pada saat dewasa (21).

Lebih lanjut, asupan natrium berhubungan positif dengan systolic blood pressure (SBP) dan merupakan 
risiko pre-high blood pressure (pre-HBP) pada anak dan remaja di Amerika dan hubungan ini lebih kuat pada mereka yang mengalami overweight maupun obesitas (20). Tekanan darah tinggi bisa dicegah dan diatasi. Kemungkinan terjadinya hipertensi dan semua penyakit yang dipicunya dapat diminimalisir dengan melakukan pola hidup yang sehat seperti pola makan yang sehat seimbang, mengonsumsi sayur dan buah, mengurangi lemak jenuh, dan mengurangi asupan garam (natrium) hingga $5 \mathrm{~g}$ per hari atau setara dengan $2.000 \mathrm{mg}$ natrium untuk anak-anak (9).

Kelemahan penelitian ini terletak pada pengukuran asupan natrium yang hanya berasal dari catatan makanan di kuesioner frekuensi makanan dan belum memasukan garam yang ditambahkan ketika memasak makanan di rumah. Sampel merupakan anak sekolah sehingga tidak paham berapa banyak garam yang ditambahkan oleh ibu mereka ketika memasak di rumah. Selain itu, pengukuran tekanan darah dilakukan tiga kali pada saat yang bersamaan dengan pengumpulan data yang lain karena izin pengumpulan data yang diberikan dari sekolah hanya satu kali supaya tidak mengganggu jam belajar.

Penelitian ini membuktikan bahwa adanya kecenderungan menyukai makanan yang asin atau mengandung natrium tinggi dimulai sejak anakanak. Kesukaan rasa asin makanan anak-anak sudah mulai berada di atas level yang dianjurkan kesehatan. Kelebihan natrium bermanifestasi terhadap risiko hipertensi sebagai salah satu penyakit tidak menular yang umumnya terjadi pada orang dewasa, tetapi saat ini juga banyak terjadi pada usia muda. Makanan yang berhubungan dengan penyakit ini akan berefek dalam waktu lama dan membutuhkan waktu bertahun-tahun untuk bermanifestasi sehingga mencegah terjadinya hipertensi ini dapat meningkatkan kualitas hidup dan menghemat biaya pengobatan (25).

\section{SIMPULAN DAN SARAN}

Pola konsumsi makanan tinggi natrium dan rendah natrium persentasenya hampir sama pada kedua kategori sering dan jarang. Jumlah responden dengan asupan natrium yang dianjurkan masih lebih banyak dibandingkan responden dengan asupan yang melebihi anjuran $(<2000 \mathrm{mg})$. Anak-anak termasuk pada kategori hipertensi menunjukkan proporsi yang cukup besar $(35,8 \%)$ dan hal ini membutuhkan perhatian yang serius. Anak yang mengonsumsi makanan tinggi natrium dengan frekuensi sering, asupan natriumnya juga akan cenderung tinggi. Berat badan anak berhubungan dengan tekanan darah sistolik dan diastolik. Tidak ditemukan korelasi antara asupan natrium dengan tekanan darah sistolik maupun diastolik pada anak. Kebiasaan makan dan asupan natrium belum bermanifestasi klinik ke tekanan darah mengingat usia responden yang masih anak-anak.

Perlu dilakukan pemberian informasi dan edukasi kepada masyarakat dan dilakukan sedini mungkin mulai dari anak-anak mengenai pemilihan makanan yang baik untuk mencegah asupan natrium yang tinggi. Penggunaan garam dalam makanan sehari-hari dan makanan olahan perlu mulai diperhatikan, mengingat kesukaan rasa asin makanan yang relatif lebih dari anjuran kesehatan sudah mulai terjadi pada usia anak sekolah. Informasi dan edukasi mengenai cara mempertahankan berat badan ideal perlu dilakukan sejak anak-anak.

\section{UCAPAN TERIMA KASIH}

Terima kasih yang sebesar-besarnya kepada Kementerian Kesehatan Republik Indonesia dan Poltekkes Kemenkes Semarang atas dana hibah bersaing yang diberikan lewat Risbinakes 2015.

\section{Pernyataan konflik kepentingan}

Tidak ada konflik kepentingan dalam penelitian ini.

\section{RUJUKAN}

1. WHO. Salt reduction. [series online] 2014 [cited 19 Jan 2015]. Available from: URL: http://www.who.int/ mediacentre/factsheets/fs393/en/

2. WHO. World heart day: salt reduction saves lives. [series online] 2014 [cited 19 Jan 2015]. Available from: URL: http://www.who.int/mediacentre/news/notes/2014/saltreduction/en/

3. Kementerian Kesehatan RI. Riset kesehatan dasar 2013. Jakarta: Badan Penelitian dan Pengembangan Kesehatan; 2014. 
4. Riley M, Bluhm B. High blood pressure in children and adolescents. American Family Physician 2012;85(7):693700.

5. Kuciene R, Dulskiene V, Medzioniene J. Association of neck circumference and high blood pressure in children and adolescents: a case-control study. BMC Pediatrics 2015;(15):127.

6. Chen X, Wang Y. Tracking of blood pressure from childhood to adulthood. Circulation 2008;117(25):317180 .

7. Chobanian AV, Bakris GL, Black HR. The seventh report of the Joint National Committee on prevention, detection, evaluation, and treatment of high blood pressure: the JNC 7 report. JAMA 2003;289(19):2560-72.

8. Rosner B, Cook NR, Daniels S, Falkner B. Childhood blood pressure trends and risk factors for high blood pressure: the NHANES experience 1998-2008. Hypertension 2014;62:247-54.

9. Center for Disease Control and Prevention. Trends in prevalence of excess dietary sodium intake-United States 2003-2010. Morbidity and Mortality Weekly 2013;62:1021-5.

10. Allen NB, Siddique J, Wilkins JT. Blood pressure trajectories in early adulthood and subclinical atherosclerosis in middle age. JAMA 2014;311:490-7.

11. Gopinath B, Louie JCY, Flood VM, E Rochtchina E, Baur LA, Mitchell P. Parental history of hypertension and dietary intakes in early adolescent offspring: a population-based study. J Hum Hypertens 2014;28(12):721-5.

12. World Health Organization. Guideline: sodium intake for adults and children. Geneva: WHO; 2012.

13. National High Blood Pressure Education Program Working Group on High Blood Pressure in Children and Adolescents. The fourth report on the diagnosis, evaluation, and treatment of high blood pressure in children and adolescents. Pediatrics 2004;114(2 Supp):555-76.

14. Webster JL, Dunford EK, Neal BC. A systematic survey of the sodium contents of processed foods. Am J Clin Nutr 2010;91(2):413-20.
15. Persatuan Ahli Gizi Indonesia. Penuntun Diit. Jakarta: Gramedia Pustaka Utama; 2010.

16. Matsuzuki H, Muto T, Haruyama Y. School children's salt intake is correlated with salty taste preference assessed by their mothers. Tohoku J Exp Med 2008;215:71-7.

17. Reinivuo H, Valsta LM, Laatikainen T, Tuomilehto J, Pietinen P. Sodium in the Finnish diet: trends in dietary sodium intake and comparison between intake and 24-hour excretion of sodium. Eur J Clin Nutr 2006;60(10):1160-7.

18. Subardja D. Obesitas primer pada anak: diagnosis, patogenesis dan patofisiologi. Edisi ke-1. Bandung: Kiblat; 2004.

19. Centers for Disease Control and Prevention. Vital signs: Food categories contributing the most to sodium consumption - United States, 2007-2008. Morbidity and Mortality Weekly 2011;61:92-8.

20. WHO. Preventing chronic disease: a vital investment. [series online] 2014 [cited 19 Jan 2015]. Available from: URL: http://www.who.int/chp/chronic_disease_report/ contents/en/index.html

21. Yang Q, Zhang Z, Kuklina EV, Fang J, Ayala C, Merritt R. Sodium intake and blood pressure among US children and adolescents. Pediatrics 2012;130(4):611-9.

22. Conliffe C, Frankson M, Smith F, Hanna-Mahasel C, Oriakhi M. Prevalencia de la Hipertensión en Adolescentes en Nassau, Bahamas. West Indian Med J 2015;64(1):17-22.Huriyati E,

23. Julia M. Tekanan darah siswa sekolah dasar obes dan tidak obes di kota Yogyakarta. Jurnal Gizi Klinik Indonesia 2014;6(2):60-3.

24. Borah PK, Devi U, Biswas D, Kalita HC, Sharma M, Mahanta J. Distribution of blood pressure \& correlates of hypertension in school children aged 5-14 years from North east India. Indian J Med Res 2015;142:293-300.

25. Murray CJ, Lauer JA, Hutubessy RC. Effectiveness and costs of interventions to lower systolic blood pressure and cholesterol: a global and regional analysis on reduction of cardiovascular-disease risk. Lancet 2003;361(9359):71725. 